\title{
A kórházak jövője, a jövő kórházai
}

\author{
Illés S. Tamás dr. \\ Service d'Orthopédie et Traumatologie, Centre Hospitalier Universitaire - Brugmann, \\ Université Libre de Bruxelles, Bruxelles, Belgique \\ Department of Orthopedic Surgery and Traumatology, Odense University Hospital and Institute \\ of Clinical Research, University of Southern Denmark, Odense, Denmark \\ Académie Nationale de Médecine, Paris, France
}

\begin{abstract}
A XX. század végére a vertikálisan szerveződő kórházak zárt hierarchikus rendszerekké formálódtak, amelyekben az egészségügyi ellátási kínálat jelentősen felaprózódott. A kórházak jelenlegi szervezettségükben nincsenek felkészülve az élettartam folyamatos emelkedésére, a multimorbiditás, valamint a krónikus és hosszan tartó betegségek számának erőteljes növekedésére, mivel azokat nem hosszú távú kezelések végzésére tervezték. A fejlett, kifejezetten drága technológiák mind gyorsabb beépülése az ellátásokba gazdasági krízist generál. Az ellátási és gazdasági krízis egyidejü megoldása nem képzelhető el a kórházak struktúrájának megváltoztatása nélkül. A jövő kórházai hálózati rendszerben, betegségprofilok szerinti szerveződésben, speciális ellátásokat fognak végezni. Jelen ismereteink szerint ez az egyetlen struktúra, amely lehetővé teszi a méretgazdaságosság elérését, a folyamatosan szúküilő források megfelelő elköltését, valamint a megváltozott betegarculat és betegségstruktúra megkövetelte hatékony betegellátás biztosítását. Orv. Hetil., 2016, 157(28), 1099-1104.
\end{abstract}

Kulcsszavak: kórházak, gazdasági válság, struktúraváltás

\section{The future of hospitals and the hospitals in the future}

By the end of the 20th century the vertically organized hospitals formed into a closed hierarchical system, in which the healthcare supply significantly fragmented. The existing hospitals in the current organization are not prepared for the increase in longevity, nor for the high growth in the number of chronic and long-term illnesses and the multimorbidity since they were not designed for extended carry treatments. The fast incorporation of high-tech and very expensive technologies into healthcare generates an economic crisis. Solving the supply and economic crisis at the same time cannot be achieved without changing the structure of hospitals. Future hospitals will be organized in a network, conducting special treatments according to disease profiles. According to present knowledge, this is the only structure that allows for economies in scale, the proper spending of the ever-shrinking resources, and to ensure the effective patient care required after the changing of disorder structures and patient corporate identities.

Keywords: hospitals, economic crisis, structural change

Illés, S. T. [The future of hospitals and the hospitals in the future]. Orv. Hetil., 2016, 157(28), 1099-1104.

(Beérkezett: 2016. március 22.; elfogadva: 2016. április 23.)

Az elmúlt évszázadok során a kórházi ellátás jelentős változáson, fejlődésen ment keresztül. A kórházak vagy ispotályok még a XVIII. században is szegény- és betegházakként múködtek. Leginkább a betegápolással foglalkozó szerzetesrendek által fenntartott jótékonysági intézmények, menedékházak voltak, ahová főleg a szegény, elesett, hozzátartozók nélküli aggok és munkaképtelenek kerültek. Az ispotályok mentális hatása azonban a betegségek köré a megbélyegzettség, kitaszítottság ké- pét rajzolta. A haldokló, nyomorult betegekkel teli fekvőcsarnokok víziója kifejezetten riasztóan hatott, emiatt „... a kórház, mint valami borzalom élt a nép tudatában. Olyan nagy volt a kórházaktól való idegenkedés, hogy a falusi ember nagyobb csapásnak tekintette kórházba jutását, mint magát a betegséget” [1].

A felvilágosodást követően jelentős változások következtek be a betegellátás területén. A kórházépítés és kórházfenntartás egyre inkább a kialakult városi polgárság 
jótékonysági tevékenységének középpontjába került, központi terepévé vált. Ennek következtében fokozatosan elkülönült egymástól a szegényellátás és a tényleges betegellátás. A kórházakban a kitaszított egzisztenciák helyett mind nagyobb számban jelentek meg a különböző betegségekben szenvedő, de alapvetően a társadalomba integrált emberek. Azzal párhuzamosan, hogy a kórházak fenntartása a nagypolgárság fennhatósága alá került, az egyházak hegemóniája háttérbe szorult. A kórházakban a betegellátást fokozatosan speciálisan képzett személyzet, valamint az orvosok vették át. A felvilágosult, szabadelvü fejlődés eredményeként a kórházak egyre inkább az orvostudomány „templomaivá” váltak az alapvetően végzett hármas tevékenység - a gyógyítás, az oktatás és a kutatás - révén.

\section{A XX. század kórháza}

A jelenlegi kórházi struktúra a XX. század első évtizedeiben kristályosodott ki. A kórházak gyakorlatilag az orvostudomány eltérő területeit leképező speciális ellátóosztályok (belgyógyászat, sebészet, gyerekgyógyászat stb.) alapjain épültek fel. Az idők folyamán az az osztályok megszaporodtak, valamint az egyes osztályokon belül jelentős technológiai hátteret igénylő szubspecialitások, szuperspecialitások is kialakultak. Ennek a fejlödésnek az eredményeként a jelenlegi kórházak vertikálisan szerveződő, az orvosi ellátás piramisának csúcsát jelentő intézményekké váltak. A magas szintű specializálódás, a fejlett technikai és technológiai színvonalú ellátás eredményeként a XX. századi kórháztörténet sikertörténetként értékelhető. Ennek a sikertörténetnek a hozadékaként jelentősen megváltozott a betegek arculata, valamint a betegségek struktúrája.

A betegarculat megváltozására jellemző a permanensen emelkedő átlagéletkor, amelynek következtében az idős betegek aránya folyamatosan nő. Míg 2000-ben a

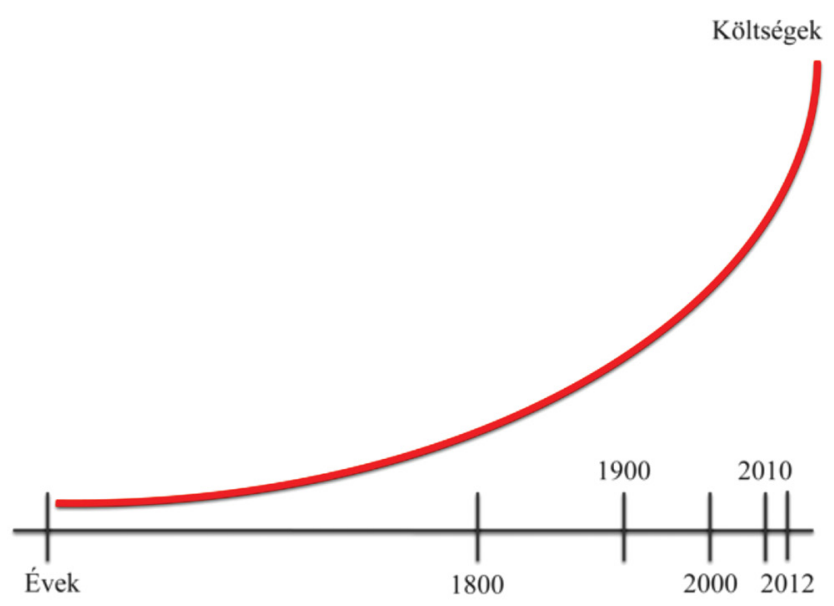

1. ábra

Egészségügyi költségrobbanás [4]. A magas technikai színvonalú drága technológiák gyors beépülése a kórházi ellátásokba költségrobbanást eredményezett, amelynek következtében az egészségügyi kiadások a nemzeti jövedelemnél kétszer gyorsabban növekednek
65 éves vagy ennél idősebb emberek részaránya 16\% körül alakult, addig 2030-ra ez az arány 24\%-ra fog növekedni, 2040-re pedig a betegek több mint harmada lesz 65 évesnél idősebb [2].

Az élettartam növekedésének velejárójaként jelentősen átalakult a betegségstruktúra is. Az átlagéletkor növekedésével párhuzamosan emelkedik az időskorban fellépó betegségek aránya. Emellett folyamatosan növekedik a krónikus és hosszan tartó betegségek előfordulásának aránya is. A krónikus betegségek számának növekedése mellett a multimorbiditás egyre gyakoribb előfordulása, a kezelések időtartamának tartós emelkedése is nyomon követhető.

\section{A fejlődés okozta válság}

A kórházi ellátás ilyen irányú fejlődése azonban hátrányokat is jelent. A fejlődés során ugyanis a kórházak nagyon zárt hierarchikus rendszerekké formálodtak, amelyekben az egészségügyi ellátási kínálat jelentősen felaprózódott. A széttagoltság azt eredményezi, hogy a jelenlegi ellátórendszer a megváltozott betegarculat és betegségstruktúra következtében egyre kevésbé tud megfelelni a modern orvostudomány aktuális kihívásainak. Ez a kórházi kezelések hatékonyságának csökkenéséhez vezet, tekintettel arra, hogy ugyanazon egészségnyereség csak egyre nagyobb ráfordítások mellett érhető el.

Az egészségügyi ellátásokra fordítandó pénzeszközök szakadatlan emelkedése gazdasági és pénzügyi válságot generál, amely folyamatosan jelen levő, egyre súlyosbodó válság, összetett okokkal. Az egyik legföbb ok - a már említett betegarculat és betegségstruktúra változása mellett - a fejlett és kifejezetten drága technológiák mind gyorsabb beépülése a kórházi ellátásokba. Ennek következményeként a fejlett országokban az egészségügyi kiadások általában kétszer nagyobb sebességgel növekednek, mint ahogy a nemzeti jövedelem emelkedik $[3,4]$ (1. ábra).

A kórházakat sújtó hatékonyságcsökkenés okai tehát egyrészt a felaprózódott ellátási struktúrából, másrészt a gazdasági nehézségekből adódnak. Ezek együttesen egyfajta ellátási „krízist” gerjesztenek, ugyanis a jelenlegi kórházi struktúrában az ellátásszerveződés [5]:

- árt a multimorbiditás több tudományágat átfogó ellátásának, ugyanis a tudományterületek széttöredezettsége révén kevéssé képes a multidiszciplináris ellátások összehangolására;

- megnehezíti a krónikus betegségek folyamatos ellátását, amely elengedhetetlen azok eredményes kezelésében;

- megakadályozza a szükséges források sokoldalú, ugyanakkor koncentrált felhasználását, ezen keresztül a méretgazdaságosság elérését.

A kórházak hatékonyságának javítása céljából az ellátásszervezők olyan intézkedéseket fogadtak el, amelyek célja egyrészt a finanszírozási kockázat csökkentése, más- 
részt a struktúra átalakításának előmozdítása volt. A finanszírozási kockázat csökkentésére a HBCS-alapú átalányfinanszírozás, a fejkvóta, a teljesítményvolumenkorlát (TVK) vagy kockázatmegosztás bevezetését ajánlották. Az ellátási struktúra megváltoztatására az ambuláns, illetve az egynapos ellátások elterjesztését, a mátrix kórház bevezetését, valamint olyan kiegészítő struktúrák, mint például az otthon ápolás, krónikus ellátási osztályok vagy rehabilitációs osztályok felállítását kezdeményezték.

A fenti struktúrák fejlesztése azonban nem hozta meg a kívánt hatást sem a kórházi ágyak hatékony kihasználásának, sem a költségek csökkentésének tekintetében. A járóbeteg-ellátás irányába történt elfordulás ellenére a kórházi fekvőbeteg-ellátások iránti igény globálisan állandó maradt.

Fontos hangsúlyozni, hogy a jelenlegi egészségügyi rendszerben nagyon nehéz tartani a gazdaságosságot. $\mathrm{Az}$ ágazatban megjelenő gazdasági problémák ugyanis elsősorban következmények és a kórházak felépítéséből, valamint az ellátás szerveződéséből következnek. A kórházak jelenleg nincsenek felkészülve a populáció állandó folyamatos öregedéséből adódó betegségstruktúra megváltozására, a multimorbiditás, valamint a krónikus betegségek számának erőteljes növekedésére. A jelenlegi kórházakat ugyanis nem hosszú távú kezelések végzésére tervezték. A gazdasági nehézségek sikeres megoldása feltételezi a betegek és betegségek jellemzőinek megváltozásából eredő ellátási krízis egyidejű megoldását is, amely nem képzelhető el a fekvőbeteg-ellátó rendszer struktúrájának megváltoztatása nélkül.

A kórházak strukturális változását kikényszerítő tényezők közül a legfontosabbak $[5,6]$ :

- A demográfiai és epidemiológiai változások, összekapcsolódva a kezelések hatékonyabbá válásával, folyamatosan növelik az átlagéletkort, amelynek következtében, illetve párhuzamosan egyre növekszik a krónikus betegségek előfordulásának aránya is.

- A gazdaságosság kényszere, amely arra kell irányuljon, hogy az ellátások színvonalának csökkenése nélkül megálljon az egészségügyi kiadások nemzeti jövedelemhez mért aránytalanul magas növekedése.

- A folyamatos technológiai és terápiás innováció, amely lehetővé tette/teszi mind a diagnosztika, mind a terápia területén azokat az áttöréseket, amelyek támogatják az előre jelző és a megelőző orvoslás elterjedését.

- Az információs technológiák, valamint a kommunikáció fejlődése egyre nagyobb szerepet játszik az egészségügyi szolgáltatások portfoliójában. Ezek a technológiák megkönnyítik és elősegítik új munkamódszerek, valamint együttmúködések kialakítását nemcsak az egészségügyi szakemberek, hanem a betegek és az egészségügyben dolgozók között is.

- A betegek viselkedésének megváltozása. A betegek egyrészről aktívabban kívánnak részt venni saját egészségük alakításában, a betegségeik megelőzésében, amely az egyének aktív részvételén alapuló, személyre szabott orvoslás kialakítását igényli. Másrészről a betegeknek egyre nagyobbak a betegellátó rendszerrel szemben támasztott elvárásaik. A betegek által elvárt ellátás és annak minősége különbözik attól, amit az egészségügy jelenleg nyújtani képes. Ebból adódóan számottevő mind a betegek, mind az egészségügyben dolgozó személyzet frusztrációja, amely alapvető konfliktusforrás!

- Az egészségügyi szakmai profilok módosulása a megváltozott elvárások következtében, amely az egészségügyi szakemberek alkalmazkodását követeli meg a több tudományágat átfogó ellátások biztosításának érdekében. Ez egyfajta kevert orvosi tudás kifejlődésének irányába hat.

\section{A XXI. század kórháza - betegellátó hálózat}

A változásra kényszerítő tényezők együttes hatására a jelenlegi kórházi struktúránál gazdaságosabb és hatékonyabb rendszerek kialakítása elkerülhetetlennek látszik a célból, hogy reagálni tudjon mind a krónikus betegségek számának erôteljes növekedésére, mind a populáció állandó öregedésére, mind pedig a betegek megváltozott elvárásaira [7].

A struktúraváltás nehézsége, hogy míg a gazdasági kényszer a magas technikai hátteret igénylő diagnosztikai eszközök, terápiás ellátások, intervenciós lehetőségek, mútőkapacitások erőteljes központosításának, centralizációjának irányába hat, addig az időskorban fellépő, krónikus, hosszan tartó betegségek vagy többszörös betegségek kezelése nagyszámú közepes és/vagy hosszú távú tartózkodásra és ellátásra specializálódott decentralizált egység kialakítását igényli. A két egymással gyökeresen ellentétes cél együttesen csak az ellátások új rendszertani szempontok szerint történő speciális megosztása révén valósítható meg. Ez csak úgy képzelhető el, hogy a kórházak specializálódnak egy bizonyos típusú betegek ellátására, azaz a kórházi ellátások betegségprofilok mentén szerveződnek.

Ahhoz azonban, hogy az ellátások további megosztása mellett megszûnjön a kórházakra már amúgy is jellemző terápiás széttagoltság, a szolgáltatások, az ellátási kínálat és a kezelések összehangolása is elengedhetetlennek tünik. Ez betegellátási hálózatok (patient care network) kialakítása felé tereli a jelenleg még kifejezetten kórházcentrikus rendszert [6].

A betegellátó hálózatok kialakítása során legegyszerúbb az akut és a krónikus ellátási formákat szétválasztani. A szervezés során feltétlenül fel kell használni a már meglevő és múködő ellátórendszereket. A fekvőbetegellátó egységeket azonban olyan formában kell átalakítani, hogy azok lehetőleg csak azonos jellegü betegek ellátására specializálódjanak. A rendszer része kell legyen egy, az akut betegek ellátására szerveződött fejlett diagnosztikai, műtőkapacitással, intervenciós lehetőségekkel, valamint jelentős intenzív és szubintenzív háttérrel ren- 

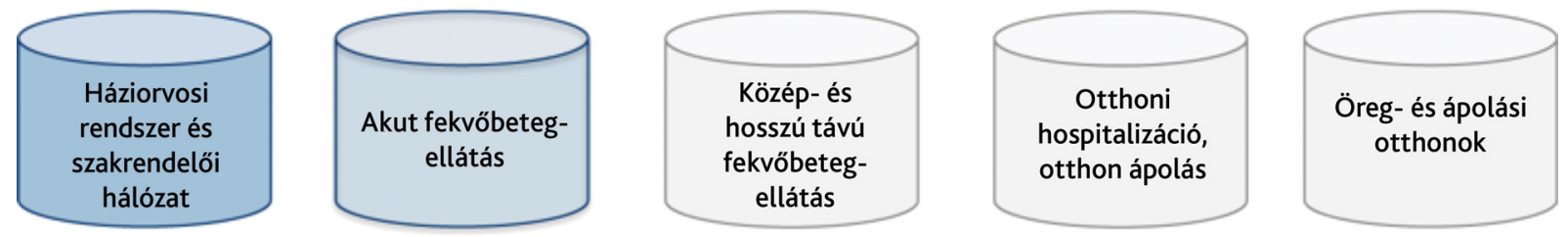

2. ábra

A horizontális betegellátó hálózat elemei [6]. A hálózat elemei között az együttmúködés kifejezetten szoros, lehetővé téve az egyes elemek közötti gyors átjárást, így biztosítva az ellátás folytonosságát

delkező kórház. Az ilyen akut kórház mellett több, főleg közép- és hosszú távú szubakut és krónikus kezeléseket vagy rehabilitációt végző kórház múködne.

A fenti elvek alapján a betegellátó hálózat elemei a következőkben határozhatók meg [6] (2. ábra):

Akut ellátási egységek:

- háziorvosi rendszer és szakrendelői hálózat,

- akut kórházi ellátás.

Krónikus ellátási formák:

- háziorvosi rendszer és szakrendelői hálózat,

- közép- és hosszú távú kórházi ellátás,

- otthoni hospitalizáció és otthon ápolás,

- öreg- és ápolási otthonok.

A betegellátó hálózatoknak úgy kell múködnie, mint a „közlekedőedények”, ahol a rendszert alkotó egyes elemek közötti együttmúködés kifejezetten szoros. Ez lehetővé teszi és egyúttal biztosítja az egyes elemek közötti gyors átjárást, garantálva ezzel az ellátás folytonosságát. A rendszerben részt vevő minden szereplő egyenrangú, aminek eredményeképpen a kórházi kezelés csak egy állomása lesz az ellátásnak, de semmiképpen sem a piramis csúcsán helyezkedik el. E szervezeti felépítés eredményeként a jelenlegi vertikális betegellátási rendszer átalakul horizontális ellátási hálózattá $[5,6]$.

\section{Akut kórház}

$\mathrm{Az}$ akut fekvőbeteg-ellátást végző intézmény tevékenysége a diagnosztikus és mútői kapacitás által behatárolt, így a magas technikai és technológiai hátteret igénylő diagnosztikai eszközök, intervenciós lehetőségek, intenzív ellátási formák, valamint a mútőkapacitások jelentős részének centralizációja ide kell, hogy összpontosuljon. $\mathrm{Az}$ intézmény az év minden napján, a nap 24 órájában ugyanolyan intenzitással folyamatosan üzemel. Itt kerülnek ellátásra a kritikus állapotú, intenzív kezelésre szoruló, jelentős diagnosztikus és terápiás kapacitást igénylő betegek. Ugyancsak itt történik a bizonytalan vagy nem ismert patológiájú, számottevő diagnosztikus erőforrást lekötő betegek kivizsgálása, majd esetleges mútéti terápiája is.

Akut betegellátásnak minősül ugyanakkor speciális ellátórendszert igényelhet a biztosan ismert patológiájú betegek erősen protokollizált ellátása. A relatíve szúk diagnosztikai hátteret igénylő ellátásokat rövid akut kórházi bentfekvés mellett el lehet végezni. Ennek egyik legjobb példája a nagyízületi protetikai mütétek végzése [8] vagy a szürke hályog mütéti ellátása. Ezeknek a protokollizált beavatkozásoknak az elvégzésére egy részidőben (hétfő́től péntekig) múködő ellátóegység hozható létre (protokollizált kórház). Az utókezelést és a rehabilitációt, ha szükséges, már egy krónikus ellátóintézmény tudja elvégezni.

\section{Krónikus kórház}

Krónikus ellátást végző intézményekben az aktív gyógyszeres és/vagy eszközös, közép- és hosszú távú terápiát igénylő betegek mellett a krónikus és/vagy komorbid betegek, valamint aktív kezelést már nem igénylő betegek hosszú távú ellátása történne. Idesorolhatók még az aktív rehabilitációs kezelést végző intézmények, valamint az otthonkórházak és az öreg- vagy ápolási otthonok rendszere is. Tekintettel arra, hogy a krónikus ellátóintézményekben koncentrálódna az aktív eszközös és/ vagy gyógyszeres kezelések jelentős része, a kezelések végzéséhez szükséges magas szintű eszközpark, valamint a kezelések hatékonyságát monitorozó eszközállomány ezekbe az intézményekbe kerülne telepítésre. Ezekben az egységekben a diagnosztikai háttér csak az alapvető mindennapi ellátást segítő diagnosztikára kellene, hogy korlátozódjon [5].

Az ellátási hálózat szerves és egyenrangú részét képezi a háziorvosi rendszer, valamint a szakrendelői hálózat, amely egyaránt részt vesz mind az akut, mind a krónikus ellátásokban. Ezeknek az ellátási formáknak a fejlesztése, erősítése és támogatása az egyénre szabott orvoslás elterjesztése, az általános egészségi állapot javítása, valamint a fekvőbeteg-ellátás igénybevételének csökkentése céljából (kapuőri szerep) elengedhetetlen.

\section{A megvalósíthatóság alapja és feltételei}

A jövő kórházai új struktúrában, az interdiszciplináris ellátásokat előtérbe helyezve, a professzionalizmusra koncentrálva kell múködjenek. A változásokat a jelenleg rendelkezésre álló, az erőforrások felmérése és méreteinek kiigazítása után, a különböző szereplők különböző céljainak összehangolásával megalkotott stratégiák mentén lehet és kell megvalósítani. A túlméretezett fekvőbetegellátó rendszerek profiltisztítás, esetleg profilváltás révén, a szolgáltatások intézményi projektek köré történő igazítása árán, az új elvárásoknak megfelelően átalakíthatók. Az ellátóhálózatok legegyszerúbben területi szervező- 
désben - régiók szerint - alakíthatók ki, ahol egy ellátóhálózathoz rendelt populáció nagysága nem haladja meg a 0,8-1,0 millió lakost. Ez a méret elegendően nagy a mérethatékonyságot és az eszközkoncentrációt illetően, ugyanakkor kellően kicsi a hatékony munkaszervezés, az egyes ellátóegységek múködésének eredményes összehangolhatósága tekintetében [6].

\section{Személyi háttér}

A megváltozó kórházi struktúra, valamint a megváltozott betegségstruktúra megköveteli az orvosi tudás adaptációját is a jövő kórházaiban. Az akut kórházakban mind a diagnosztikában, mind az akut ellátásokban egyegy területen magasan képzett, a rohamosan fejlődő technikai háttérhez gyorsan alkalmazkodó és azt alkalmazó orvosokra van szükség. A krónikus kórházakban azonban az orvosi ellátásokban mindinkább előtérbe kerülő interdiszciplináris kezelések összetett képességű és tudású szakembereket igényelnek. Ez a kettősség eltérő, egymással nem helyettesíthető és nem összevethető, ugyanakkor egymással egyenértékű, kifejezetten magas színvonalú szakmai tudást igényel. Ez a kettősség a szakemberképzés megváltozott igényekhez történő folyamatos adaptálását is szükségessé teszi.

\section{Informatikai háttér}

A jövő kórházainak hálózatában a hatékony múködés alapfeltétele a webtechnológiára épülő fejlett informatikai háttér, amely egyszerre lehet a szolgáltatások platformja, a szakemberek közötti együttmúködés eszköze, valamint egy kiterjesztett lehetőség a betegekkel való kapcsolattartásra.

Az informatikai háttér:

- Biztosítja a hálózat egyes elemei között az állandó kapcsolattartást, az információs csatornák hatékony múködését, a betegutak meghatározását, nyomon követését és szükség szerinti átszervezését az ellátás folytonosságának biztosítása érdekében.

- Megteremti a lehetőségét a betegekkel és kezelésükkel kapcsolatos adatok gyűjtésének, elemzésének, módot teremtve ezzel egyrészt az egészségügyi technológiák hatékonyságának analízisére, másrészt a teljes rendszer teljesítményének permanens monitorozására.

- Lehetővé teszi az ellátások és a finanszírozási ráfordítások ellenőrzését, naprakész összehasonlító elemzését, amely elengedhetetlen a gazdaságosság eléréséhez és fenntartásához.

- Megkönnyíti a betegek hozzáférését saját egészségügyi adataikhoz.

- Elősegíti új munkamódszerek és együttmúködések kialakítását nemcsak az egészségügyi szakemberek, hanem a betegek és az egészségügyben dolgozók között is.

Az informatika használatának velejárója az egészségügyi adatbiztonság kérdése. A betegekhez kapcsolódó egyéni és egészségügyi adatok fokozott védelmét biztosítva kell megteremteni az egészségügyi információk szabad áramlását, amely szükséges az új rendszer rendeltetésszerű múködéséhez.

\section{Szabályozás}

Az ellátási hálózatok létrehozásához, múködésének biztosításához speciális törvényi háttér megalkotása szükséges. A szabályozásnak kifejezetten precíznek kell lennie a rendszer egészét érintő kérdésekben, az ellátás következetes fenntartása érdekében. Ugyanakkor kellóen rugalmasnak kell bizonyulnia az ellátási hálózat egyes elemei mindennapi múködésének szabályozásában. A központi irányítás megerősítése mellett a szabályozó hatóság, valamint a betegellátást biztosító szolgáltatók kifejezetten szoros, összahangolt együttmúködése is elengedhetetlen a rendszer folyamatos, gördülékeny üzemeltetéséhez.

\section{Következtetések}

A jelenlegi kórházak jövője tehát meg van pecsételve. Nem lehet ugyanis a fennálló rendszer finanszírozását a végtelenségig emelni. Határtalan igényeket pedig nem lehet, de nem is célszerü kielégíteni [9].

A jövő kórházai hálózati rendszerben, betegségprofilok szerinti szerveződésben, speciális ellátásokat fognak végezni. Jelen ismereteink szerint ez az egyetlen struktúra, amely lehetővé teszi a méretgazdaságosság elérését, a relatíve folyamatosan szúkülő források megfelelő elköltését, valamint a megváltozott betegarculat és betegségstruktúra megkövetelte hatékony betegellátás biztosítását.

Anyagi támogatás: A közlemény megírása anyagi támogatásban nem részesült.

A szerző a cikk végleges változatát elolvasta és jóváhagyta.

Érdekeltségek: A szerzőnek nincsenek érdekeltségei.

\section{Irodalom}

[1] Gortvay, Gy.: The recent history of Hungarian medical culture and health care. [Az újabbkori magyar orvosi múvelődés és egészségügy története.] Akadémiai Kiadó, Budapest, 1953. [Hungarian]

[2] Population Ageing and Development 2012. http//www.un. org/esa/population/publications/2012PopAgeingDev_ Chart/2012PopAgeingandDev_WallChart.pdf

[3] Joint Report on Health System 2010. http//www.europa.eu/ epc/pdf/joint_healthcare_report_en.pdf

[4] Baráth, L.: The challenges of health, their answers in the 21st Century, particularly concerning the crisis. [Az egészségügy kihívásai, azok válaszai a XXI. században, különös tekintettel a válságra.] www.med.u-szeged.hu/download.php?docID $=50932$ [Hungarian] 
[5] Barrubés, J.: Rethinking the hospital: drivers of change and innovative answers. 2014. [Repenser l'hôpital: moteurs du changement et réponses innovantes.] http//www.antares-consulting. com/fr_FR/main/detallepublicacion/Publicacion/106/ap artado/H/idUnidad/3 [French]

[6] Kokoszka, V:: The hospital of the future. 2014. [L'hôpital du future.] http//www.healthcare-executive.be/fr/actualite/lhopital-du-futur [French]

[7] Baráth, L.: The new health care approach - innovative hospitals [Az egészségügy új szemlélete - innovatív kórházak.] IME, 2012, 11(4), 24-27. http://www.imeonline.hu/article. php?article=2012._XI./4/az_egeszsegugy_uj_szemlelete_innovativ_korhazak\# [Hungarian]
[8] Keblet, H., Wilmore, D. W.: Evidence-based surgical care and the evolution of fast-track surgery. Ann. Surg., 2008, 248(2), 189198.

[9] Ormos, M.: Is there any history? [Van-e történelem?] Kossuth Kiadó, Budapest, 2012. [Hungarian]

(Illés S. Tamás dr., Place Van Gehuchten 4, 1020 Bruxelles, Belgique e-mail: tamas.illes@ulb.ac.be e-mail: tamas.illes@chu-brugmann.be

„Ha minden iskolában és családban a könyvben szereplö ötletek kis töredékét felhasználnák, beláthatatlan lehetöségek nyilnának meg elöttünk, hogy javítsuk az autizmussal vagy Asperger-szindrómával élő gyermekek életminőségét. Ez pedig csodálatos dolog!"

A könyv számtalan azonnal alkalmazható ötletet kínál szülőknek és nevelőknek az alábbi területeken:

- szenzoros integráció: fejlesztőfeladatok a szabadban és bent,

- kommunikáció: szóhasználat, hallás, vizualitás, környezet,

- viselkedés: tipikus viselkedési formák és kezelésük,

- mindennapi élet: ötletek a mindennapi szituációkhoz, a biztonság megteremtéséhez,

- szociális létezés: barátság, játék, kooperáció, érzelmek. 